Proc. Indian Acad. Sci. (Earth Planet. Sci.), Vol. 101, No. 3, September 1992, pp. 299-316.

(C) Printed in India.

\title{
Neogene deep sea benthic foraminiferal diversity in the Indian Ocean: Paleoceanographic implications
}

\author{
AJAI K RAI and M S SRINIVASAN \\ Department of Geology, Banaras Hindu University, Varanasi 221005 , India \\ MS received 14 July 1992

\begin{abstract}
The species diversity indices, as defined by the number of species, $S$; ShannonWiener index, $H(S)$ and Buzas-Gibson index, $E^{\prime}$, of DSDP sites 219, 220, 237 and 238 were measured to determine the benthic foraminiferal diversity patterns in the Indian Ocean deep sea sequences during the Neogene. The Time-Stability hypothesis could satisfactorily explain the observed diversity patterns. The general patterns of diversity suggest environmental stability during the Neogene. However, few small fluctuations in diversity during the Middle Miocene (c.14.8 Ma), Late Miocene (c.6.0 Ma) and Late Pliocene (c.2.0 Ma) may possibly be the effects of Antarctic Bottom Water (AABW) activity in this region. The benthic foraminiferal diversity in the tropical Indian Ocean is more than the high latitudinal areas with comparable depthis.
\end{abstract}

Keywords. Neogene; foraminifera; species diversity; Indian Ocean; paleoceanography; Antarctic Bottom Water.

\section{Introduction}

Since very long times naturalists have observed that the number of species, whether fossil or living, varies considerably in different parts of the globe. In recent years, there have been important advances in the study of deep sea species diversity. Most of the earlier studies in species diversity were concerned with the latitudinal patterns (Fischer 1960; Simpson 1964; Pianka 1966; Valentine 1966; Kiester 1971). Commonly, species diversity increases towards the areas of low latitudes. However, Gibson (1966), Sanders (1968, 1969), Buzas and Gibson (1969), Gibson and Buzas (1973), Sen Gupta and Kilbourne (1974) and Rex (1983) observed an increasing trend of species diversity of marine invertebrates with depth and found very high species diversity at abyssal depths. This is contrary to the earlier assumptions that the deep sea benthos are much less diverse. Gibson and Buzas (1973) also suggested the extension of shallow water latitudinal diversity gradients into bathyal depths. The incorrect idea of low species diversity in many groups at abyssal depths was due to the low density of the larger invertebrates and also the problem of their adequate sampling.

In the present work, benthic foraminifera of different depths and locations were selected for the study of the species diversity because of the availability of sufficient data and a good fossil record. Benthic foraminifera have relatively high densities, a core sample usually contains several hundred to even few thousand individuals with a reasonable number of species and their proportions. Hessler and Sanders (1967) and Buzas and Gibson (1969) have suggested that the diversity patterns of foraminifera are 


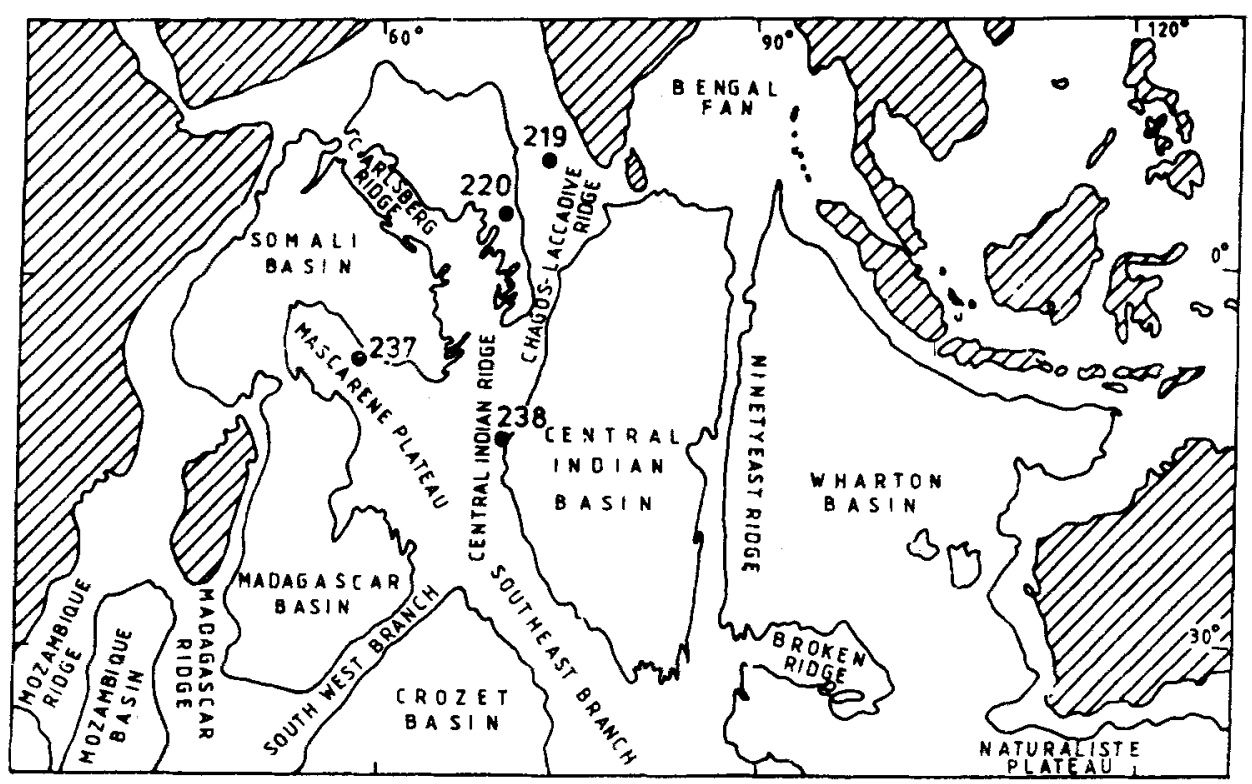

Figure 1. Physiographic features of the Indian Ocean as defined by the $4000 \mathrm{~m}$ contour (after Davies et al 1974) and the location of the DSDP sites examined.

Table 1. Location of the DSDP sites examined.

\begin{tabular}{lccccl}
\hline $\begin{array}{l}\text { DSDP } \\
\text { Leg }\end{array}$ & Site & Latitude & Longitude & $\begin{array}{c}\text { Water } \\
\text { depth }(\mathrm{m})\end{array}$ & \multicolumn{1}{c}{$\begin{array}{c}\text { Physiographic } \\
\text { province }\end{array}$} \\
\hline 23 & 219 & $9^{\circ} 01 \cdot 75^{\prime} \mathrm{N}$ & $72^{\circ} 52 \cdot 67^{\prime} \mathrm{E}$ & 1764 & $\begin{array}{l}\text { Chagos Laccadive Ridge } \\
\end{array}$ \\
24 & 220 & $6^{\circ} 30 \cdot 97^{\prime} \mathrm{N}$ & $7^{\circ} 59 \cdot 02^{\prime} \mathrm{E}$ & 4036 & Arabian Basin \\
& 237 & $7^{\circ} 04 \cdot 99^{\prime} \mathrm{S}$ & $58^{\circ} 07 \cdot 48^{\prime} \mathrm{E}$ & 1640 & Mascarene Plateau \\
& 238 & $11^{\circ} 09 \cdot 21^{\prime} \mathrm{S}$ & $70^{\circ} 31 \cdot 56^{\prime} \mathrm{E}$ & 2844 & Central Indian Ridge \\
\hline
\end{tabular}

similar to those of other marine invertebrates. In view of this, the present study will provide a better understanding of the species diversity patterns.

The benthic foraminifera examined were obtained from 390 core samples recovered from the Indian Ocean DSDP sites 219, 220, 237 and 238 (figure 1 and table 1). The fauna consists of 234 species of benthic foraminifera. A detailed quantitative analysis of this fauna was carried out to determine the foraminiferal diversity patterns in a deep sea, low latitude environment. To explain the species diversity patterns, the results were evaluated relative to some of the current theories.

\section{Material and methodology}

The principal data source for the present study is from DSDP sites 219, 220, 237 and 238 drilled during Legs 23 and 24. Sites 219, 237 and 238 contain fairly continuous Neogene sequences while at site 220 discontinuous coring precludes a detailed benthic foraminiferal biostratigraphy (figure 6). The Neogene sequences, examined from these 
sites, consist of foraminifera-rich nannofossil ooze excepting site 200 (with 4,036 m of water depth) which consists of foraminiferal nannofossil ooze with detrital clay.

Samples of approximately $10 \mathrm{cc}$ were soaked in water and boiled little before wet screening. Moderately hard samples were treated with $15 \%$ hydrogen peroxide solution. Samples, after wet sieving over 100 mesh and 150 mesh screens, were dried. All the specimens of benthic foraminifera were then picked from the entire $10 \mathrm{cc}$ sample, mounted on reference slides, identified and counted. The quantitative data generated, has been used to calculate different indices of diversity.

\section{Diversity measurement}

Defined in a most simple way, the index of diversity is the total number of species $(S)$ inhabiting a particular area. Benthic foraminiferal assemblages of deep sea are usually composed of a few abundant species and several rare ones, mostly represented by a single individual (figure 2). The sample size, however, plays an important role in controlling the total number of species. Since varying abundances of species have not been taken into account, divergent communities may have equal number of species $(S)$ showing similar diversities. Suppose two areas are represented by five species each, the species proportions of the first area are 0.90, 0.04, 0.03, 0.02 and 0.01 whereas, the second area has the proportions $0.50,0.24,0.13,0.09$ and 0.04 . If diversity is defined by the number of species then both the areas have equal diversity. However, the relative abundances of species differ in the two areas. Today, the number of species (species richness or species density) and species abundances (species equitability, evenness, or dominance) are considered as the two aspects of the same thing. Hence, species diversity refers to both number and abundance of species. In view of this, more advance indices have been used considering the significance of species according to their relative abundances.

To understand the species diversity, where both species richness and species abundance are involved, a number of workers (Fisher et al 1943; Preston 1948, 1962; Simpson 1949; Shannon and Wiener 1949; Brian 1953; Basharin 1959 and Sanders 1968) have proposed various mathematical models. The complexity of nature (especially when considering within-habitat diversity) is such that no single model seems to account reasonably for the distribution of species abundances (Gibson and Buzas 1973). Shannon-Wiener information function is the most commonly used index to understand the patterns of species diversity. Several forms of the function are available (Margalef 1957; Brillouin 1964; Pielou 1966). In the present study the number of species, $S$; the Shannon-Wiener Index, $H(S)$; and the Buzas-Gibson Index, $E^{\prime}$; have been used to describe the benthic foraminiferal diversity patterns.

The Shannon-Wiener Index, the one most commonly used, measures the average diversity per individual. It is derived from the information function. This index is defined as,

$$
H(S)=-\sum_{i=1}^{s} \mathrm{pi} \ln \mathrm{pi}
$$

where, $S$ is the number of species in the sample and pi is the proportion of the ith species in the sample. 

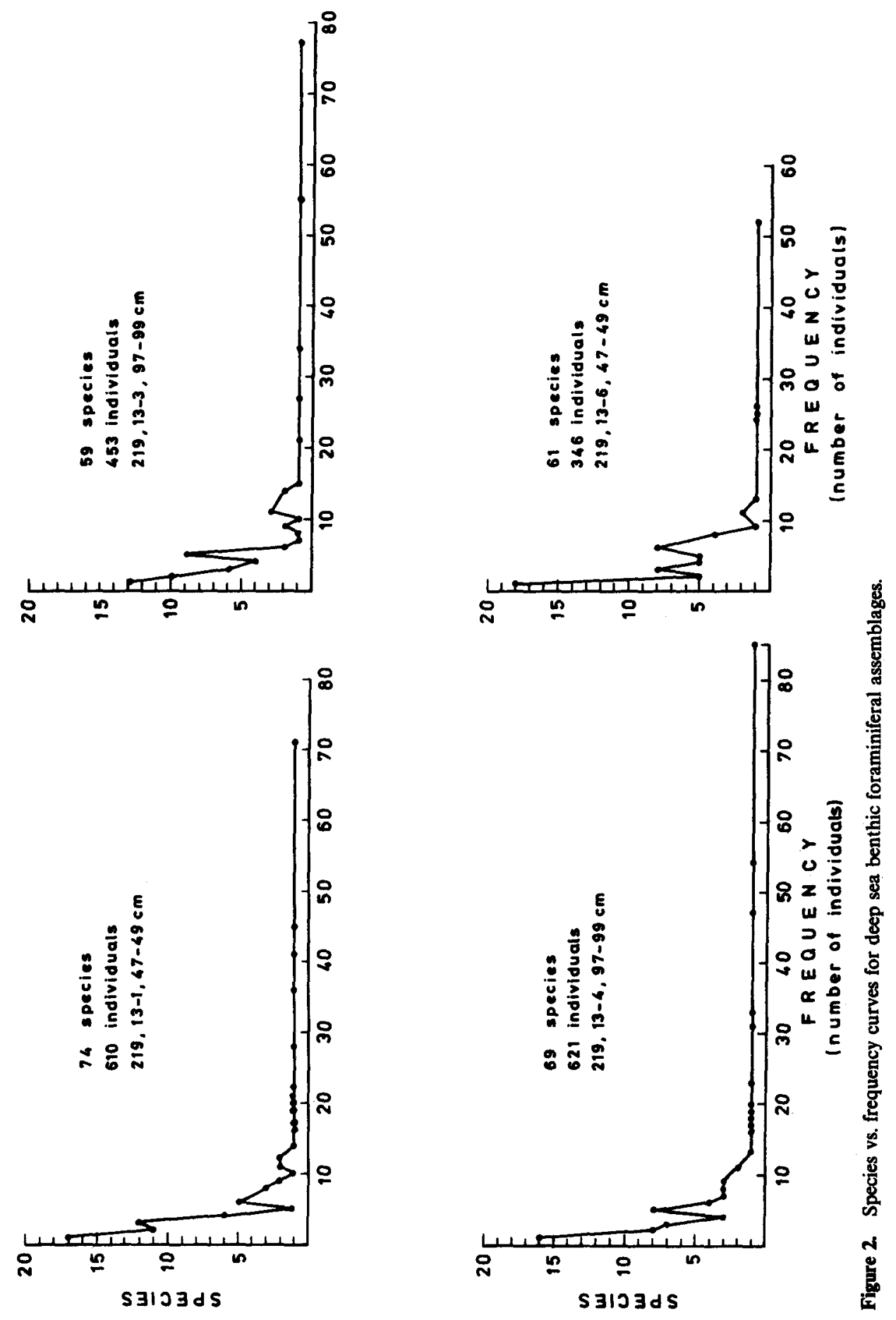
This index is not without limitations. Basharin (1959) proposed the following correction;

$$
H^{\prime}=H(S)-\frac{S-1}{2 N}
$$

where, $S$ is the number of species in the sample and $N$ is the total number of individuals in the sample. If the sample contains several hundred individuals then the above correction is very small. For the foraminiferal sample this correction is negligible and will not be used in the present study.

A number of mathematical expressions are also available for calculating the equitability. In the present study, the equation of equitability given by Buzas and Gibson (1969) has been followed. It is defined as,

$$
E^{\prime}=\frac{e^{H(S)}}{S}
$$

where $e$ is the base of Naperian (natural) logarithms and $E^{\prime}$ is the equitability. When all species are equally distributed, the equitability will be one $\left(E^{\prime}=1 \cdot 0\right)$.

The advantage of the information function index, $H(S)$, is its independence of sample size. This index is very slightly affected by rare or extremely abundant species. Whereas, species with moderate abundances have major control over this index. An increase in the sample size adds more number of rare species, however the index $H(S)$ is little affected above a certain threshold sample size.

Gibson and Buzas (1973) have attempted to explain the relationship of $S, H(S)$ and $E^{\prime}$ with the sample size based on the foraminiferal sample (figure 3). The total number of species $(S)$ increases with increasing sample size, whereas, the value of $H(S)$ remains almost constant. In this way, the use of information function $H(S)$ reduces the problem

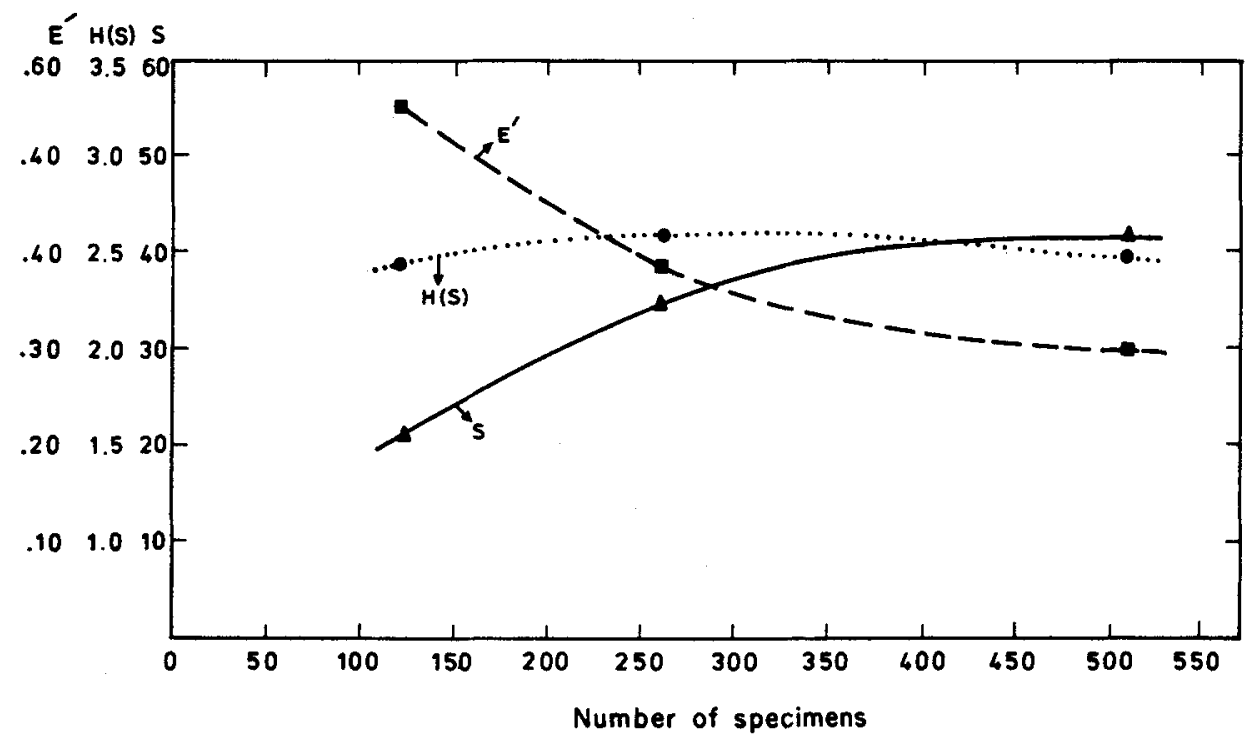

Figure 3. Plots of Number of species, $S$; Species Diversity, $H(S)$ and Equitability, $E^{\prime}$ with increasing sample size (after Gibson and Buzas 1973). 
of sample size. The value of $H(S)$ remains same throughout the range of sample size, whereas, $S$ increases due to addition of rare species with increasing sample size. Therefore, value of equitability $\left(E^{\prime}\right)$ decreases with increasing sample size, because rare species have very little effect on the value of $H(S)$. The low value of $E^{\prime}$ signifies less equitable distribution of species.

\section{Results}

The diversity measures described above were determined for the 390 samples from this study. The calculated values of the number of species; $S$, species diversity; $H(S)$ and equitability; $E^{\prime}$ are plotted in figures 4 to 10 . The general trend of curves shows that $H(S)$ remains more or less constant throughout the range during the Neogene, however, scatter in the values of $S$ and $E^{\prime}$ is quite high. In general, both the number of species per sample, $S$, and species diversity, $H(S)$ show a parallel trend with few exceptions at site 219 . In contrast to this, equitability, $E^{\prime}$ maintains an almost inverse relationship with number of species, $S$. At sites 237 and 238 values of these three indices have been integrated with the Miocene Oxygen and Carbon isotopic records of Oridorsalis umbonatus (Vincent $e t$ al 1985) for the better understanding of the relationship between the diver'sity patterns of deep sea benthic foraminifera and the bottom water paleoceanographic changes in this region.

Of the four sites examined, only at sites 219 and 237 the later part of the Early Miocene was recorded (figures 4 and 7). $S$ and $H(S)$ maintain the moderately low values during late Early Miocene which increase towards the early part of Middle Miocene (Pr. glomerosa Zone). A declining trend of $H(S)$ and $S$ has also been observed in $G r$. peripheroacuta Zone (c. 14.8 Ma) and middle and uppeı parts of $G$ r. plesiotumida Zone (late Miocene) at site 237 (figure 7). At site 238, Middle/Late Miocene boundary and the middle part of $\mathrm{Gr}$. plesiotumida Zone (early Late Miocene) are marked by sharp declines in the $H(S)$ and $S$ values (figure 9).

Low values of $H(S)$ and $S$ are recorded in the lower part of Gr. tumida tumida Zone (Early Pliocene) at sites 237 and 238 (figures 8 and 10). Few peaks of decreasing $S$ and $H(S)$ are marked also in the Sa. dehiscens Zone (Early Pliocene) and Gr. tosaensis Zone (Late Pliocene at site 238 (figure 10). At sites 219 and 237 declining trends of $S$ and $H(S)$ have been observed in the Sa. dehiscens Zone (Early Pliocene), Gr. margaritae Zone (late Early Pliocene) and Gr. tosaensis Zone (Late Pliocene) (figures 5 and 8). The early parts of Gr. truncatulinoides-tosaensis overlap Zone (Early Pleistocene) at sites 219 and 238 are also marked by decrease in the values of $H(S)$ and $S$ (figures 5 and 10 ).

The values of equitability, $E^{\prime}$ show much fluctuating trend throughout the Neogene (figures 4 to 10). This may possibly be due to the lack of any simple pattern in the species proportions. The high values of equitability signify the more equitable distribution of species in the region.

Two samples (Core 18, sections 1 and 2) in the Pu. primalis Zone at site 238 are totally devoid of benthic foraminifera (figure 9). The total absence of benthic foraminifera in these two samples is intriguing. However, laboratory error during the processing of samples can not be ruled out.

The Miocene diversity patterns at sites 237 and 238 are integrated with the Oxygen and Carbon isotopic records of benthic foraminifer, Oridorsalis umbonatus (figures 7 and 9). At some intervals viz. Gr. fohsi fohsi Zone (Middle Miocene; c. 14.0 Ma.), 
Neogene benthic foraminiferal diversity
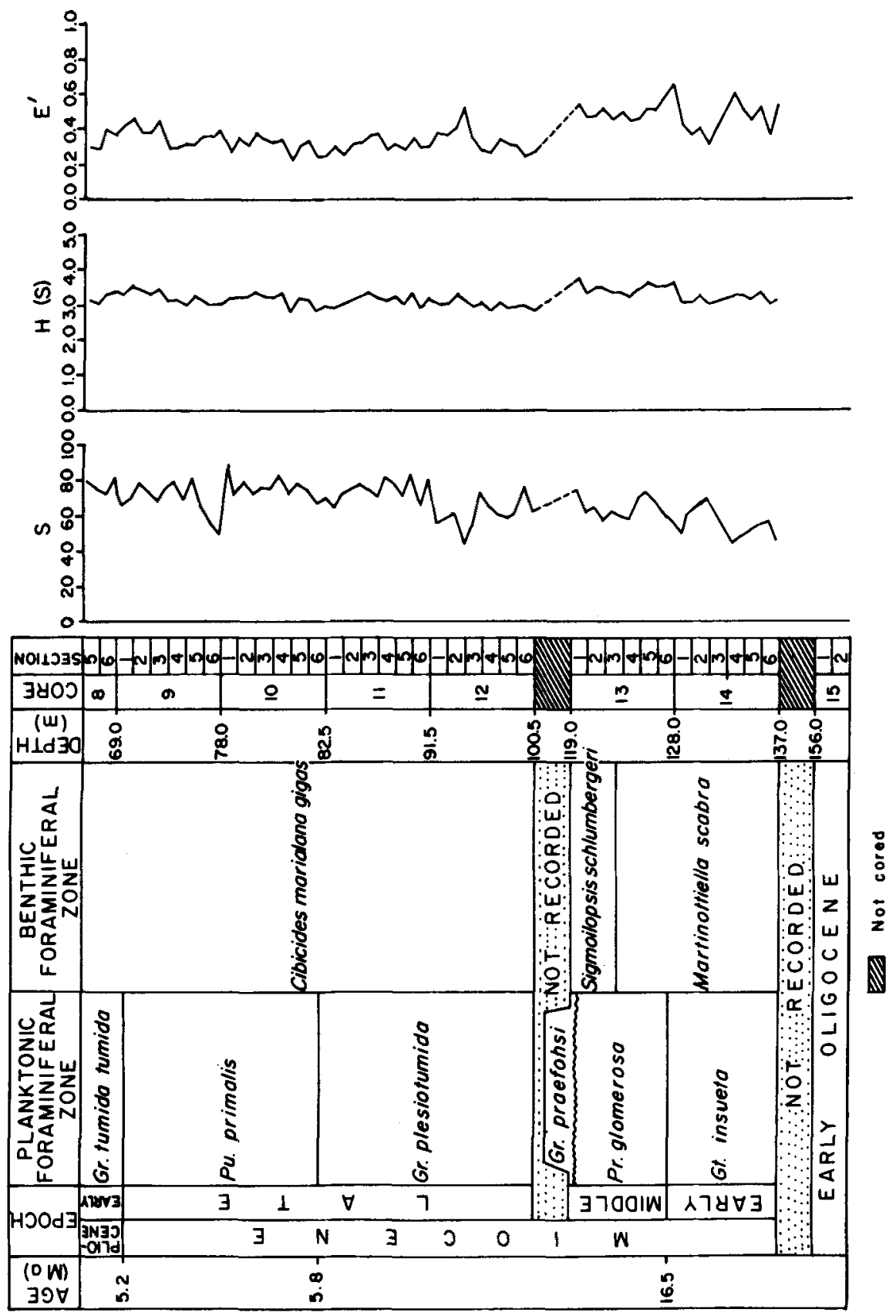


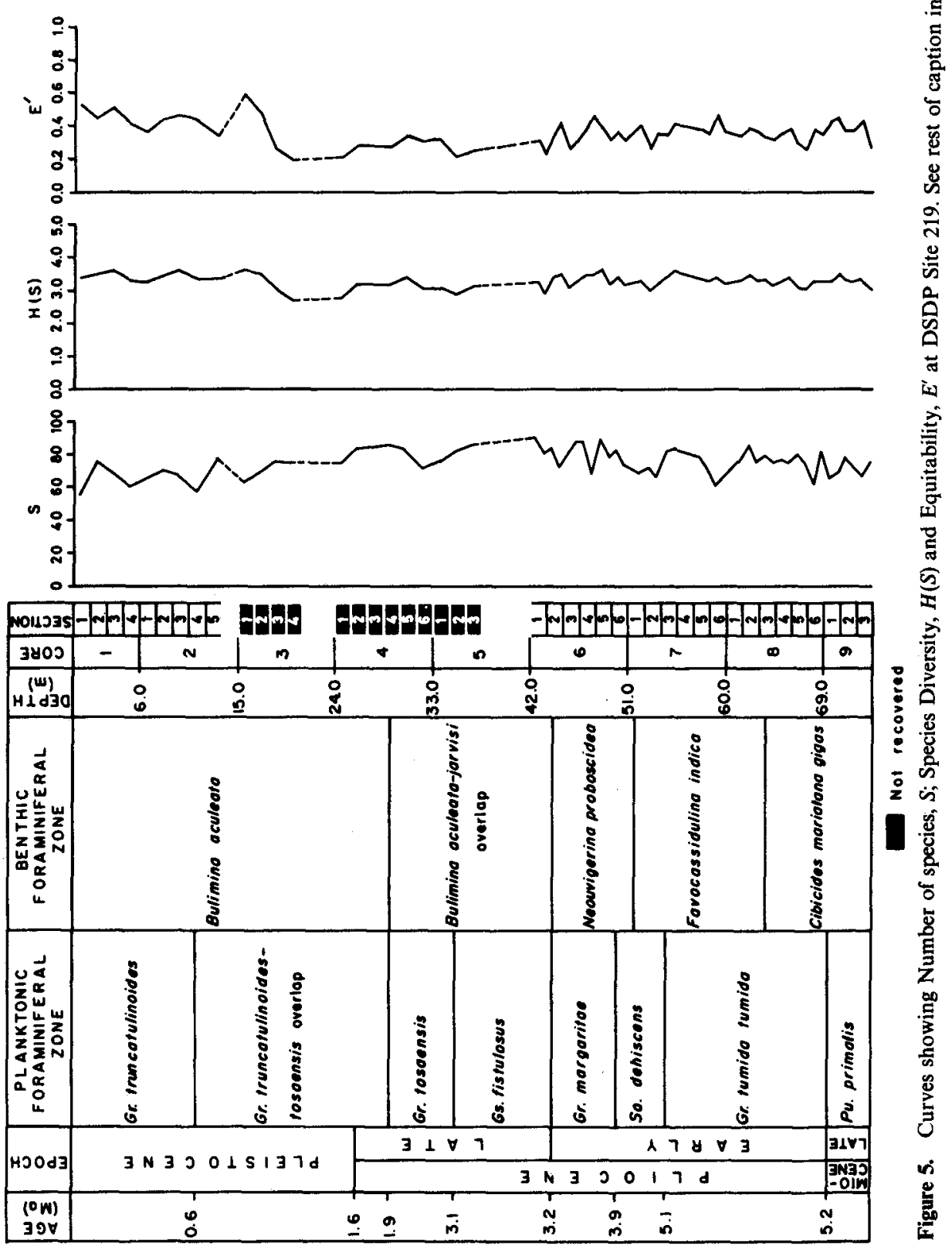



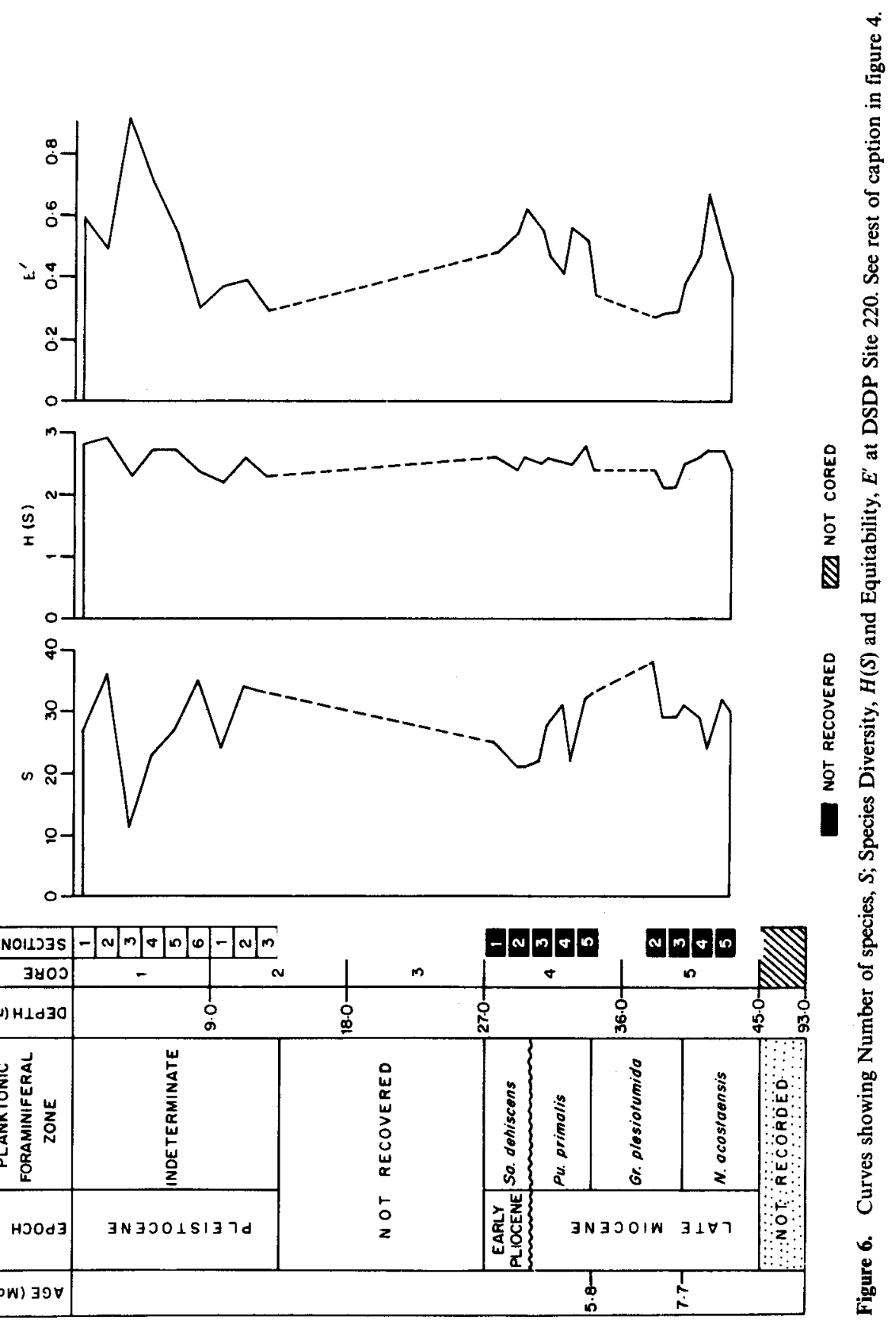


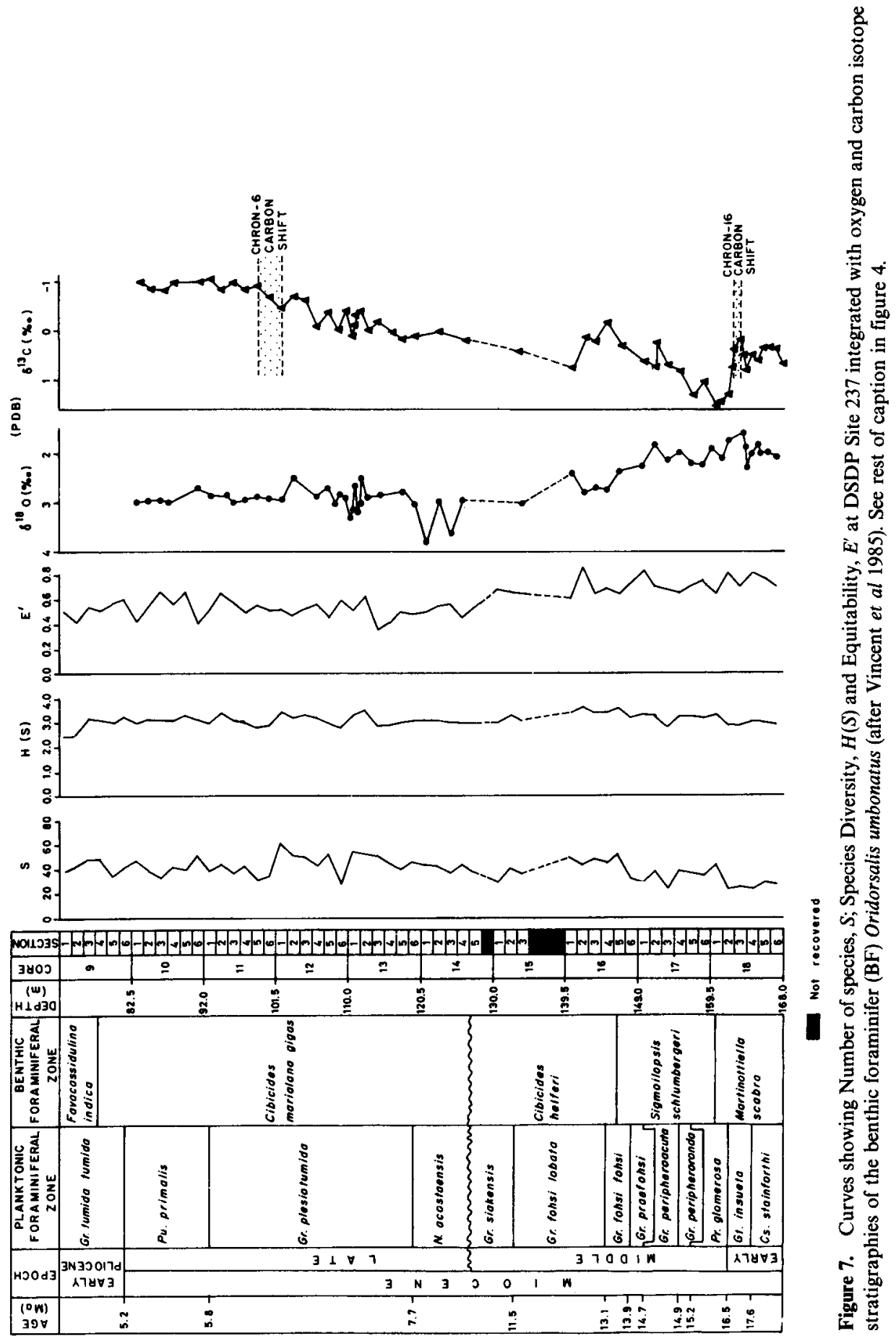




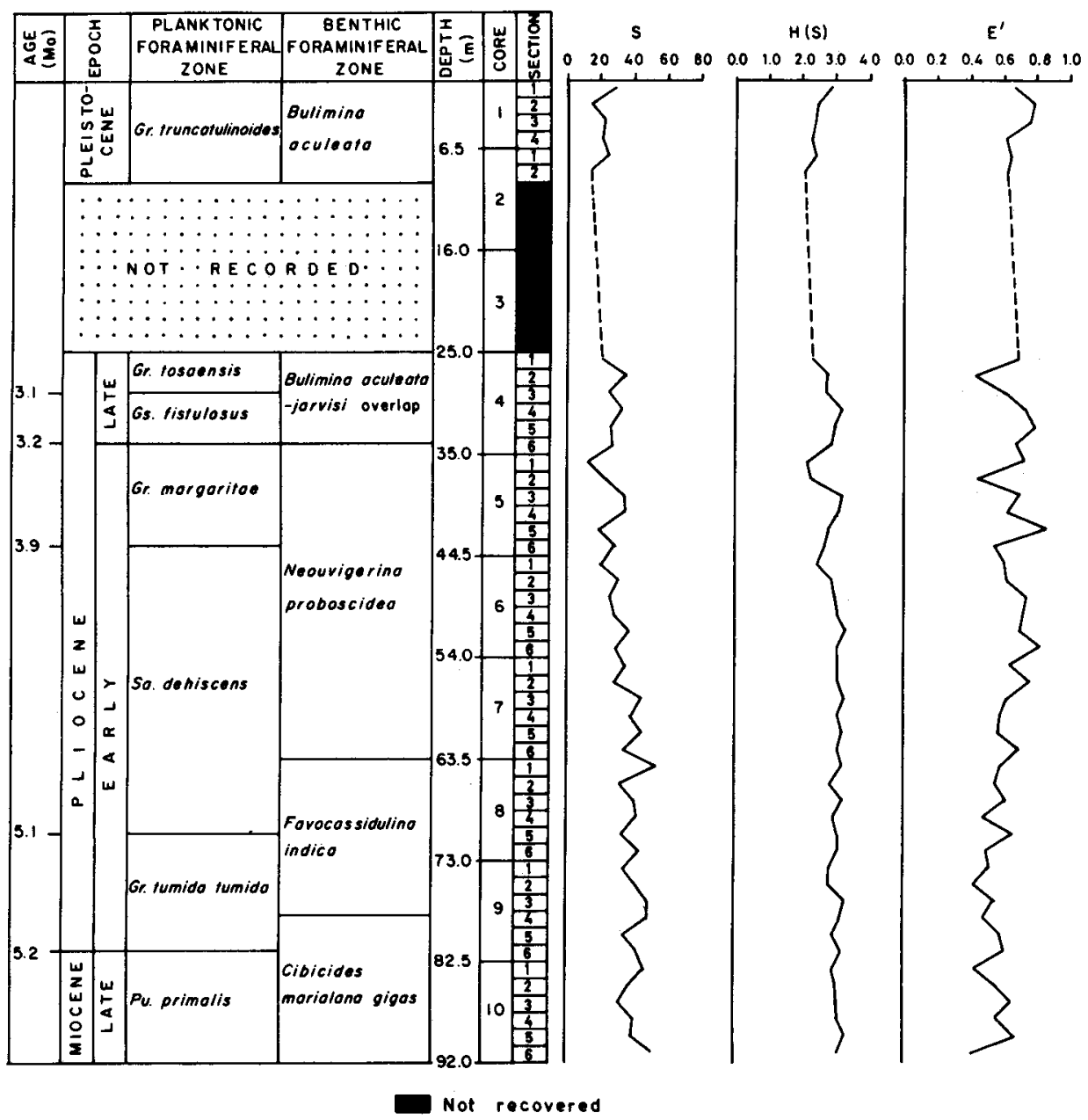

Figure 8. Curves showing Number of species, $S$; Species Diversity, $H(S)$ and Equitability, $E^{\prime}$ at DSDP Site 237. See rest of caption in figure 4.

Gr. menardii Zone (latest Middle Miocene), and Gr. plesiotumida Zone (Late Miocene) the high values of $\delta^{18} \mathrm{O}$ and low $\delta^{13} \mathrm{C}$ correspond with the decline in the benthic foraminiferal diversity.

The average diversity of the top of the cores in the present study is compared with some of the data on the foraminiferal diversities presented by Gibson and Buzas (1973), Lagoe (1976) and Gupta (1987) (table 2). Two conclusions can be drawn from this comparison. Species diversity of the Indian Ocean is very high than the other high latitude areas like Arctic region whereas, it is very close to the other low latitude areas with comparable depths (i.e. Gulf of Mexico Deltas). 

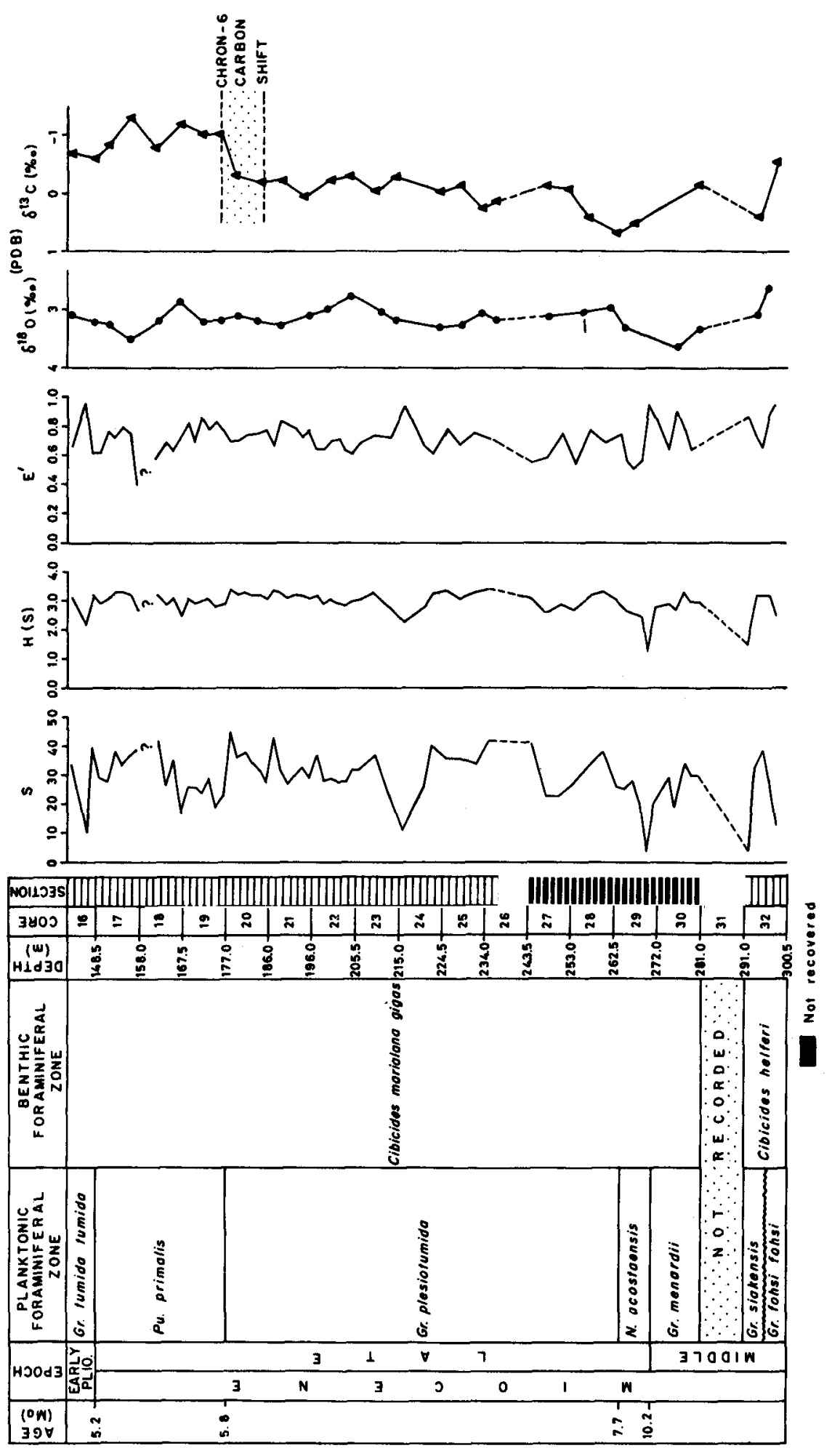

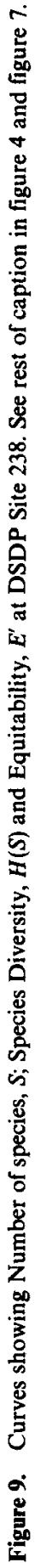



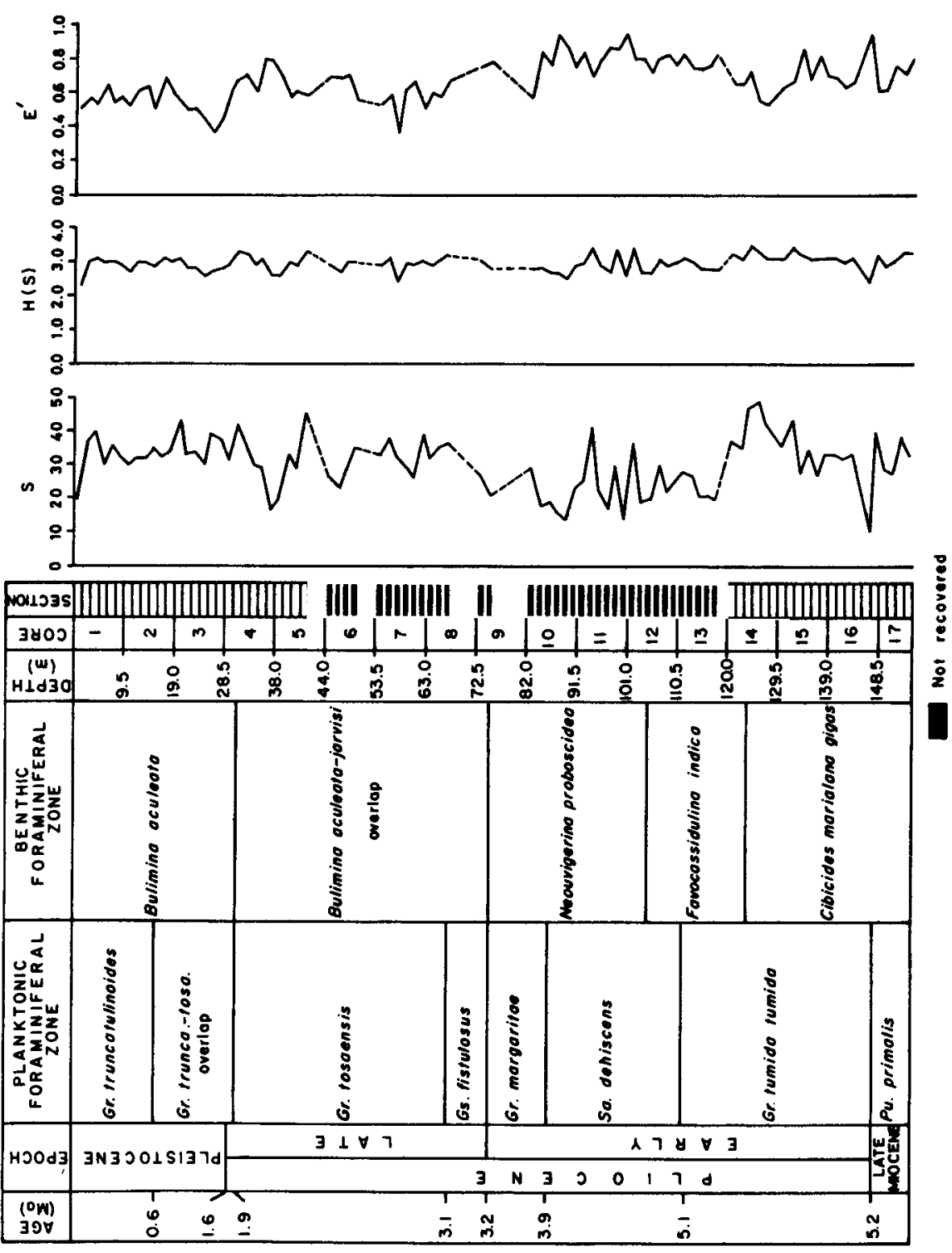

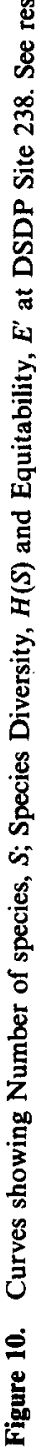


Table 2. Comparison of diversity measures for the Indian Ocean and other marine environments.

\begin{tabular}{|c|c|c|c|c|c|c|c|}
\hline Area & $\begin{array}{l}\text { Depth range } \\
(m)\end{array}$ & $s$ & Range & $H(S)$ & Range & $E^{\prime}$ & Range \\
\hline Present work & $1640-4036$ & $33 \cdot 0$ & $20-57$ & $2 \cdot 88$ & $2 \cdot 32-3.41$ & 0.58 & $0.51-0.66$ \\
\hline $\begin{array}{l}\text { Northern Indian } \\
\text { Ocean (Gupta 1987) }\end{array}$ & $1665-3030$ & $51 \cdot 2$ & $46-59$ & $3 \cdot 10$ & $2 \cdot 50-3 \cdot 40$ & 0.44 & $0.28-0.58$ \\
\hline $\begin{array}{l}\text { Central Arctic } \\
\text { Ocean (Lagoe 1976) }\end{array}$ & $1069-3709$ & $16 \cdot 2$ & $8-24$ & 1.79 & $0.59-2.28$ & 0.39 & $0.16-0.65$ \\
\hline${ }^{*}$ Canadian Arctic & $0-100$ & $17 \cdot 2$ & $12-25$ & 1.99 & $1.49-2.22$ & 0.45 & $0.33-0.66$ \\
\hline${ }^{*}$ Canadian Arctic & $100-1000$ & 16.8 & $12-24$ & 1.96 & $1.48-2.26$ & 0.44 & $0.32-0.62$ \\
\hline $\begin{array}{l}\text { * Cape Cod to } \\
\text { Maryland }\end{array}$ & below 1000 & $48 \cdot 0$ & $28-83$ & $2 \cdot 62$ & $1 \cdot 81-3.55$ & 0.31 & $0.15-0.47$ \\
\hline $\begin{array}{c}\text { *Cape Hatteras } \\
\text { to Florida }\end{array}$ & below 1000 & $78 \cdot 0$ & $72-83$ & 3.23 & $3 \cdot 17-3 \cdot 26$ & $0 \cdot 32$ & $0.31-0.33$ \\
\hline $\begin{array}{l}\text { *Northeast } \\
\text { Gulf of Mexico }\end{array}$ & below 1000 & $57 \cdot 9$ & $35-91$ & $3 \cdot 25$ & $2 \cdot 73-3.94$ & 0.47 & $0.34-0.71$ \\
\hline $\begin{array}{l}\text { *Northwest } \\
\text { Gulf of Mexico }\end{array}$ & below 1000 & $11 \cdot 7$ & $9-14$ & $2 \cdot 18$ & $1 \cdot 82-2 \cdot 39$ & 0.77 & $0.64-0.91$ \\
\hline $\begin{array}{l}\text { *Gulf of Mexico } \\
\text { Deltas }\end{array}$ & below 1000 & $45 \cdot 3$ & $14-60$ & $2 \cdot 99$ & $0.91-3.54$ & 0.49 & $0.18-0.60$ \\
\hline
\end{tabular}

*From Gibson and Buzas (1973).

\section{Discussion and interpretation}

The present knowledge about the ecologic and biologic parameters, which actually determines the species diversity patterns of any community is very scanty. Many workers have already proposed different theories to explain the species density and diversity patterns. Among these are environmental stability (Klopfer 1959; Fischer 1960 and Dunbar 1960), time (Fischer 1960 and Simpson 1964), competition (Dobzhansky 1950 and Williams 1964), predation (Paine 1966), availability of nutrients or productivity (Connell and Orias 1964), spatial heterogeneity (Simpson 1964) and various combinations such as productivity-stability and time-stability (also see Pianka 1966 and Brookhaven National Laboratory 1969). Thus no single hypothesis could satisfactorily explain the diversity patterns of deep sea benthic foraminifera (Lagoe 1976).

Margalef (1963) was of the view that the undisturbed communities would evolve from immature to mature ecosystems. He (op cit.) stated that a changing or unstable ecosystem will be less diverse than a more stable environment, which later paved the way to establish time-stability hypothesis.

The time-stability hypothesis (Hessler and Sanders 1967; Sanders 1968, 1969 and Slobodkin and Sanders 1969) was attempted to understand the relation between species and environmental dynamics. Sanders (1969) believed that due to stability of physical environments over long geologic time extensive biological interactions and accommodations have taken place which yielded more diverse fauna in the region through the niche partitioning. However, in contrast to the above, in physically unstable environments the species diversity will be low. This is because of the lack of 
adaptability in the extreme environments (Gibson 1966) and high rate of extinctions (Slobodkin and Sanders 1969). A precise definition of ecological stability is, however, difficult to obtain (Margalef 1969). It is also not easy to have a quantitative approach of stability and a diversity-stability equation because of the insufficient understanding about the real ecosystem (Deevey 1969).

According to Connell and Slater (1977) under some optimal physical stresses opportunistic species compete with specialists, which increase the diversity. The disappearance of specialized stenotopic species and dominance of opportunistic (eurytopic) species take place under the higher levels of environmental disturbances, while the reverse is true in the extreme stability conditions. Recently, Huston (1979) proposed a Dynamic Equilibrium Model suggesting that the natural communities exist in a nonequilibrium condition because of the changing nature of biological interactions and fluctuations in the physical stresses (Osman 1977; Caswell 1978; Connell 1978 and Sousa 1979). A decrease in the species diversity is expected towards equilibrium stage because of displacement by dominant competitors. While, species diversity increases under the disturbances of moderate intensity in biotic or physical stresses. Moore (1983) and Kaminski (1984) have also supported this theory.

Gupta and Srinivasan (1990) suggested that the time-stability hypothesis would best explain the deep sea benthic foraminiferal diversity patterns. Authors are also of the view that the above theory would possibly be more appropriate to interpret the deep sea benthic foraminiferal diversity patterns in the Indian Ocean.

In the examined DSDP sites, the entire section from top to bottom is composed of monotonous lithology suggesting homogeneity of the substrate. Few foraminiferal tests are partly bored (not completely eliminated) by the predators showing the evidence of predation, which is not as significant to control the species diversity patterns in the region (Gupta and Srinivasan 1990). Thus the nature of substrate and predation do not seem to play any vital role in this region to define the benthic foraminiferal diversity patterns.

In the deep sea, primary food production does not take place except near the hydrothermal vents and the food supply is in the form of organic matters which settle down through the water column (Rex 1981). Since, the depths of deposition of the studied sequences are high $(>1600 \mathrm{~m})$, it is suggested that species diversity would be independent of the availability of food supply.

In the present study, factors related to the environmental dynamics seem to play the major role in defining the benthic foraminiferal diversity patterns. This may be either due to vertical sea-floor tectonism (deepening or shallowing of sea basin) or the effect of increased Antarctic Bottom Water (AABW) activity in this region. The isotopic data for the Miocene benthic foraminifera (Vincent et al 1985) signify the role of Antarctic Bottom Water (AABW) in changing the environmental stability which in turn also changes the quality and quantity of the benthic fauna and their species diversity measures.

In general, the constant high values of species diversity, $H(S)$ throughout the range of examined sites reveal almost stable deep sea environmental conditions in the Indian Ocean during the Neogene. However, declines in the value of species diversity during the Middle Miocene (c.14.8 Ma), Late Miocene (c.6.0 Ma), Early Pliocene (c.5.0 Ma) and Late Pliocene (c.2.0 Ma) mark the periods of unstable environments in this region. The above periods of unstability can satisfactorily be explained by understanding the evolution of Antarctic glaciation, the Circum-Antarctic circulation patterns and their 
impacts on the global paleoceanography (Kennett 1977). The reactivation of Antarctic Bottom Water (AABW) due to formation of Antarctic ice sheet in Middle Miocene, major global cooling and the resultant global sea level regression in Late Miocene, and northern hemisphere cryospheric evolution and subsequent oscillations during Late Pliocene may be the plausible explanations for the instability of the Indian Ocean environmental conditions which in turn is reflected in the low diversity of benthic foraminifera. The high values of species diversity at some intervals suggest the more stable deep sea conditions which may be due to the diminishing Antarctic Bottom Water (AABW) activity.

The higher benthic foraminiferal diversity of the Indian Ocean and other low latitudinal areas with comparable depths (table 2) seems to be due to the more mature ecosystem and also the stable nutrient supply in these regions as compared with other high latitudinal areas. Thus, both the water depth and geographic location have a significant role in determining the diversity patterns of benthic foraminifera.

\section{Conclusions}

The study of different diversity measures of the Neogene benthic foraminifera from DSDP sites $219,220,237$ and 238 in the Indian Ocean led to the following conclusions:

1. In general, the constant high values of species diversity, $H(S)$ throughout the Neogene appear to be due to more mature Indian Ocean ecosystem and stable nutrient supply.

2. However, the plausible explanations for the marked declines in the species diversity at some intervals are;

(i) The decline in the value of species diversity during Middle Miocene (c. 14.8 Ma) appears to be due to the Antarctic ice sheet formation.

(ii) The Late Miocene (c. $6.0 \mathrm{Ma}$ ) decrease in the species diversity seems to be the effect of major global cooling and the resultant global sea level regression. The isotopic records with enriched $\delta^{18} \mathrm{O}$ and low $\delta^{13} \mathrm{C}$ values at sites 237 and 238 also signify the role of the above global phenomenon in controlling the Indian Ocean deep sea environments.

(iii) The decline in the species diversity during Late Pliocene (c. $2.0 \mathrm{Ma}$ ) also marks the instability of the Indian Ocean deep sea environments which may possibly be due to the northern hemisphere cryospheric evolution and the subsequent oscillations.

3. The prominent increase in the values of species diversity at some intervals marks the warming of the Indian Ocean bottom waters. This may be the effect of waned bottom water activity due to reduced influence of Antarctic Bottom Water (AABW) in the examined sites.

4. The tropical Indian Ocean foraminiferal diversity is similar to the other low latitude areas with comparable depths but higher than those of high latitudinal regions.

\section{Acknowledgements}

Deep Sea Drilling Project is acknowledged for providing core samples. Financial support was given by Council of Scientific and Industrial Research, New Delhi as S.R.F. 


\section{References}

Basharin G P 1959 On a statistical estimate for the entropy of a sequence of independent random variables, in Artin N (ed.) Theory of probability and its applications, Vol. 4, Philadelph., Indus. Appl. Math. Soc., 333-336

Berggren W A, Kent D V and Van Cauring J A 1985 Neogene geochronology and chronostratigraphy, in Geochronology and the record, Geological Society London, Special Paper, (ed.) N J Snelling pp. 211-260

Brian M V 1953 Species frequencies in random samples from animal populations; J. Anim. Ecol. 22 57-64

Brillouin L 1964 Scientific uncertainty and information (New York: Academic Press) pp. 164

Brookhaven National Laboratory 1969 Diversity and stability in ecological system; Brookhaven Symp. Biol. 22 pp. 264

Buzas M A and Gibson T G 1969 Species diversity: Benthonic foraminifera in the Western North Atlantic; Science 163 72-75

Caswell H 1978 Predator - mediated coexistence: A nonequilibrium model; Am. Nat. 112 127-154

Connell J H 1978 Diversity in tropical rain forests and coral reefs; Science 199 1302-1310

Connell $\mathrm{J} \mathrm{H}$ and Orias E 1964 The ecological regulation of species diversity; Am. Nat. $98399-414$

Connell J H and Slater R D 1977 Mechanism of succession in natural community, stability and organization; Am. Nat. 111 1119-1144

Davies T A, Luyedyk B P, Rodolfo K S, Kempe D R C, Leidy Rd, Horvath G J, Hyndman R D, Thierstein H R, Herb R C, Boltovskoy E and Doyle P 1974 Initial Rep. Deep Sea Drill. Proj. 26 1-1129

Deevey E S 1969 Specific diversity in fossil assemblages, in diversity and stability in the ecological systems; Brookhaven Natl. Lab. Symp. Biol. 22 224-241

Dobzhansky T 1950 Evolution in the tropics; Am. Sci. 38 209-221

Dunbar M J 1960 The evolution of stability in marine environments. Natural selection at the level of the ecosystem; Am. Nat. 94 129-136

Fischer A G 1960 Latitudinal variation in organic diversity; Evolution 14 64-81

Fisher R A, Corbett A S and Williams C B 1943 The relation between the number of species and number of individuals in random sample of animal population; J. Anim. Ecol. 12 42-58

Gibson L B 1966 Some unifying characteristics of species diversity; Cushman. Found. Foraminiferal. Res. Contrib. 17 117-124

Gibson T G and Buzas M A 1973 Species diversity patterns in modern and miocene foraminifera of the eastern margin of North America; Geol. Soc. Am. Bull. 84 217-238

Gupta A K 1987 Neogene deep water benthic foraminifera from the Northern Indian Ocean (DSDP Leg 22) Ph.D. Thesis, Banaras Hindu University, Varanasi (Unpublished)

Gupta A K and Srinivasan M S 1990 Species diversity of Neogene deep sea benthic foraminifera from the Northern Indian Ocean DSDP sites 214 and 216A, in Fourth Int. Symp. on Benthic Foraminifera, Sendai, Japan, (Abstr.) p. 53

Hessler R R and Sanders H L 1967 Faunal diversity in the deep sea; Deep-Sea Res., 14 65-78

Huston M 1979 A general hypothesis of species diversity; Am. Nat. 113 81-101

Kaminski M A 1984 Evidence for control of abyssal agglutinated foraminiferal community structure by substrate disturbance: results from the HEBBLEA Area, in Deep Ocean Sediment Transport (eds) Nowell and Holister, p. 113-131

Kennett J P 1977 Cenozoic evolution of Antarctic glaciation, the Circum-Antarctic Ocean and their impact on global paleoceanography: J. Geophys. Res. 82 3843-3860

Kiester A R 1971 Species diversity of North American amphibians and reptiles; Syst. Zool. 20 127-137

Klopfer P H 1959 Environmental determinates of faunal diversity; Am. Nat. 93 337-342

Lagoe M B 1976 Species diversity of deep sea benthic foraminifera from the Central Arctic Ocean: Geol. Soc. Am. Bull. 87 1678-1683

Margalef R 1957 La teoria de la informacion en ecologia, R. Acad. Cienc. Artes Barcelona Mem. 32 373-449

Margalef R 1963 On certain unifying principle in ecology; Am. Nat. 97 357-374

Margalef R 1969 Diversity and stability : A practical proposal and a model of interdependence; Brookhaven Symp. Biol. 22 25-37

Moore P D 1983 Ecological diversity and stress; Nature (London) 30617

Osman R W 1977 The establishment and development of marine epifaunal community; Ecol. Monogr. 47 37-63

Paine R T 1966 Food web complexity and species diversity; Am. Nat. 100 65-75

Pianka E R 1966 Latitudinal gradients in species diversity: A review of concepts; Am. Nat. $10033-46$ 
Pielou E C 1966 The measurement of diversity in different types of biological collections; J. Theor. Biol. 13 131-144

Preston F W 1948 The commonness and rarity of species; Ecology 29 254-283

Preston F W 1962 The canonical distribution of commonness and rarity, pt. I and pt. II; Ecology, 43 185-215, 410-432

Rex M A 1981 Community structure in the deep sea benthos; Annu. Rev. Ecol. Syst. 12 331-353

Rex M A 1983 Geographic patterns of species diversity in the deep sea benthos; in The Sea, (ed.) Gilbert T Rowe 8 453-472

Sanders H L 1968 Marine benthic diversity: A comparative study; Am. Nat. 102 243-282

Sanders H L 1969 Benthic marine diversity and the stability-time hypothesis, in diversity and stability in ecological system: Brookhaven Natl. Lab Symposia in Biology 22 71-81

Sen Gupta B K and Kilbourne R T 1974 Diversity of benthic foraminifera on the Georgia continental shelf; Geol. Soc. Am. Bull. 85 969-972

Shannon C E and Wiener W 1949 The mathematical theory of communication, Univ. of Illinois Press, Urbana III, pp. 125

Simpson E H 1949 Measurement of diversity; Nature (London) 163688

Simpson G G 1964 Species diversity of North American recent mammals; Syst. Zool. 13 57-73

Slobodkin L B and Sanders H L 1969 On the contribution of environmental predictability to species diversity, in diversity and stability in ecological systems; Brookhaven Natl. Lab. Symp. Biol. 22 82-95

Sousa W P 1979 Disturbance in marine intertidal boulder fields: The nonequilibrium maintenance of species diversity; Ecology 60 1225-1239

Srinivasan M S 1988 Late cenozoic sequences of Andaman-Nicobar Islands: Their regional significance and correlation; Indian J. Geol. 60 11-34

Srinivasan M S and Kennett J P 1981 Neogene planktonic foraminiferal biostratigraphy and evolution: Equatorial to Subantarctic, South Pacific; Mar. Micropal. 6 493-533

Srinivasan M S, Rai A K and Gupta A K 1992 Neogene benthic foraminiferal biostratigraphy of the Indian Ocean deep sea sequences, in Proc. of 79th Indian Science Congress, Baroda, (Abstr.) Sect. VII, p. 19-20

Valentine J W 1966 Numerical analysis of marine molluscan ranges on the extra-tropical northeastern Pacific shelf; Limnol. Oceanogr. 11 198-211

Vincent E, Killingley J S and Berger W H 1985 Miocene carbon and oxygen isotope stratigraphy of the tropical Indian Ocean, in The Miocene (ed.) J P Kennett; Geol. Soc. Am. Mem., USA 163 103-130

Williams C B 1964 Patterns in the balance of nature and related problems in quantitative ecology, (New York: Academic Press) pp. 324 